\title{
Identifikasi Bahaya Keselamatan dan Kesehatan Kerja pada Penangkapan Ikan Nelayan Muroami
}

\author{
Health and Safety Hazards Identification in Muroami Fishing
}

\author{
Dimas Ari Dharmawirawan, Robiana Modjo
}

Departemen Keselamatan dan Kesehatan Kerja Fakultas Kesehatan Masyarakat Universitas Indonesia

\begin{abstract}
Abstrak
Kelautan Kepulauan Seribu pada tahun 2009 terdapat 1.722 penduduk berprofesi sebagai nelayan. Sebanyak 299 orang berprofesi nelayan muroami yang menghadapi bahaya keselamatan dan kesehatan kerja tinggi dan hingga saat ini mereka belum mengetahui bahaya pekerjaan tersebut. Penelitian deskriptif dengan analisis kualitatif ini, bertujuan mendapatkan gambaran bahaya kegiatan penangkapan ikan nelayan muroami di Kelurahan Pulau Panggang, Kabupaten Kepulauan Seribu. Penelitian ini hanya mengamati para penyelam kompresor sebagai subjek penelitian dengan mengunakan metode identifikasi bahaya yaitu Job Hazard Analysis. Bahaya keselamatan dan kesehatan kerja pada tahapan aktivitas penangkapan ikan terdiri atas tahapan persiapan, tahapan penyelaman, dan tahapan penanganan hasil penangkapan. Bahaya yang dihadapi dikelompokkan menjadi bahaya bagi keselamatan dan bahaya kesehatan, bahaya bagi keselamatan pekerja meliputi ombak, lantai licin, duri ikan, terjepit, bahan bakar mesin kompresor, selang api korosif, tekanan udara pada tabung mesin kompresor, tuas terlepas, karang, gigitan biota laut, selang tertekuk, terputus, atau bocor dan tubuh yang tersangkut baling-baling kapal. Bahaya kesehatan meliputi ergonomik, kebisingan, tekanan ekstrim, temperatur dingin, temperatur panas, sengatan ikan dan karang beracun, gas $\mathrm{CO}, \mathrm{CO}_{2}$ dan nitrogen.

Kata Kunci: Penangkapan ikan, nelayan, penyelam kompresor
\end{abstract}

\begin{abstract}
Data from Fisheries and Maritime Affairs Thousand Islands goverment in 2009 there were 1722 people living as fishermen, with 299 people living as muroami fishermen. Muroami Fishermen is one of the informal sector jobs which have high dangers of occupational health and safety, until now the fishermen don't know the danger of their jobs. The study is descriptive with the approach of this qualitative analysis, aims to find the description on the danger of muroami fishing activities catch of fish, in Kelurahan Panggang Island, Thousand Islands District. This study only observed without inter-
\end{abstract}

vention to the compressor divers as subjects of research. Hazard identification methods used Job Hazard Analysis. The results obtained OHS hazard description of fishing activities, consisting of: stage of preparation, 2. Stages Stage diving and handling of the arrest. Based on these stages, found the picture hazards can be classified into 2, namely: a danger to the safety of workers (the waves, the ship slippery floors, thorn fish, stuck, compressor fuel, corrosive fire hose, air pressure in the tube compressor machines, lever regardless, the coral, marine biota bites, the bent hose, the hose is disconnected, the hose is leaking and body caught in the propeller ship) and health hazards (ergonomics, noise, extreme pressure, cold temperatures, hot temperatures, and fish stings toxic reef, gas $\mathrm{CO}, \mathrm{CO} 2$ and nitrogen).

Key words: Catch of fish, fisherman, compressor divers

\section{Pendahuluan}

Keselamatan dan kesehatan kerja (K3) secara menyeluruh dapat dijelaskan bahwa setiap pekerja berhak memperoleh pelayanan keselamatan dan kesehatan kerja terlepas dari status sektor ekonomi formal atau informal, besar kecilnya perusahaan, dan jenis pekerjaan. Berdasarkan penjelasan tersebut, K3 saat ini sangat dibutuhkan oleh hampir semua pekerjaan dari aspek sektor industri formal dan informal. Perkembangan dan pertumbuhan kedua sektor industri tersebut selalu diiringi dengan masalah besar kecelakaan kerja dan penyakit akibat kerja. ${ }^{1}$ Salah satu aktivitas pekerjaan yang mempunysi bahaya K3 adalah kegiatan menyelam

Alamat Korespondensi: Robiana Modjo, Departemen Keselamatan dan Kesehatan Kerja FKM Universitas Indonesia, Gd. C Lt. 1 Kampus Baru UI Depok 16424,Hp.081511609731,e-mail: 71.bian@gmail.com 
yang dilakukan di bawah permukaan air, dengan atau tanpa menggunakan peralatan, untuk mencapai tujuan tertentu. Berdasarkan pada tujuan, kegiatan penyelaman dapat dimanfaatkan secara komersial untuk kepentingan konstruksi di bawah permukaan air, penambangan lepas pantai salvage, penangkapan ikan. ${ }^{2}$ Aktivitas menyelam mengandung risiko bahaya $\mathrm{K} 3$ jika pelaksanaan menyimpang dari prosedur. Seluruh pelaku dalam kelompok masyarakat selam memiliki tanggung jawab dan kewajiban untuk mengurangi risiko bahaya K3. Berdasarkan hasil penelitian yang dilakukan oleh PARAS consulting Ltd, ${ }^{3}$ dari 1000 kasus kecelakaan selam yang didapat dari hasil laporan kecelakaan penyelaman wisata yang disusun oleh British Sub Aqua Club (BSAC) dan Divers Alert Network, terdapat 286 kasus kematian akibat penyelaman.

Penyelam tradisional di Indonesia adalah nelayan yang melakukan penyelaman untuk mendapatkan hasil tangkapan ikan. Nelayan penyelam tradisional yang sering disebut dengan nelayan kompresor yaitu penyelam yang menggunakan peralatan sangat terbatas. Kebanyakan hanya terdiri dari kompresor yang biasa digunakan untuk memompa ban kendaraan bermotor, fin, masker, selang dengan regulator dan pemberat dari timah. Berdasarkan alat tangkap, nelayan kompresor yang menggunakan jaring biasa disebut dengan nelayan muroami. ${ }^{4}$ Muroami termasuk dalam drive-in net yang menangkap ikan dengan menggiring ikan ke dalam alat tangkap jenis apa saja. ${ }^{5}$

Penyelaman secara tradisional oleh nelayan muroami tersebut merupakan salah satu pekerjaan di sektor informal yang menurut Bali statement on Occupational Health Safety in the informal sector, terdiri dari bisnis skala kecil, bisnis keluarga, dan usaha mikro yang lain. Umumnya, bisnis ini merupakan usaha sendiri dan melibatkan anggota keluarga. Keselamatan dan kesehatan kerja di sektor informal dipengaruhi oleh beberapa faktor dalam proses kerja, faktor manusia, dan lingkungan kerja meliputi hazard di tempat kerja atau kondisi kerja yang kurang sehat. Faktor penyebab dalam proses kerja adalah material yang ber-hazard, prosedur dan keterampilan kerja, dan perlindungan mesin. Faktor manusianya seperti tingkat pendidikan yang rendah, gizi kurang, dan peralatan pelindung diri yang tidak sesuai. Hazard pada lingkungan kerja termasuk aspek fisika, kimia, biologi, ergonomi dan psikososial. ${ }^{6}$

Berdasarkan hasil survei terhadap nelayan kompresor di Kelurahan Pulau Panggang, Kabupaten Kepulauan Seribu, Jakarta Utara yaitu sebanyak 145 responden yang diperiksa, ternyata 111 menderita penyakit umum dan penyelaman. Di antara 81 responden menderita penyakit khusus penyelaman meliputi barotrauma telinga, dekompresi, dan penyakit akibat lingkungan dalam air. Sebanyak 47 orang nelayan kom- presor yang diteliti ditemukan 35 orang yang menderita ketulian. Dengan demikian, salah satu kasus kesehatan yang muncul akibat kegiatan penyelaman adalah gangguan pendengaran. ${ }^{7}$

Berdasarkan observasi ditemukan gambaran umum K3 pada nelayan kompresor meliputi: pertama bahaya K3 yang ada di lingkungan kerja seperti bahaya K3 fisik, bahaya K3 mekanik, bahaya K3 biologi, kimia, dan bahaya K3 psikososial. Kedua, kurang waspada terhadap faktor risiko terhadap terjadi penyakit akibat kerja meliputi dekompresi, barotrauma, keracunan dan sinus. Ketiga, keterbatasan peralatan yang dipergunakan. Keempat, beban fisik yang tinggi dan waktu kerja yang lama. Kelima, pengetahuan nelayan kompresor mengenai safety dive yang rendah. Keenam, tidak ada upaya pencegahan terhadap hazard atau bahaya K3 yang ada.

\section{Metode}

Penelitian ini merupakan penelitian observasional deskriptif dengan pendekatan analisis kualitatif terhadap kegiatan penangkapan ikan nelayan muroami di Kelurahan Pulau Panggang, Kabupaten Kepulauan Seribu Jakarta. Penelitian ini dilakukan di Kelurahan Pulau Panggang, Kabupaten Kepulauan Seribu, Jakarta Utara, pada periode November sampai dengan Desember tahun 2009. Penarikan sampel dilakukan secara purposif dan jumlah yang sedikit, agar validitas tetap terjaga dilakukan uji validitas triangulasi, yang meliputi triangulasi sumber, triangulasi metode, dan triangulasi data. Triangulasi sumber digunakan untuk menggali informasi secara mendalam, penelitian ini menggunakan empat orang informan, meliputi 2 orang nelayan muroami yang tinggal di Kelurahan Pulau Panggang dan masih melakukan kegiatan penangkapan ikan dengan menggunakan kompresor sebagai penyuplai udara dalam proses penyelaman, 1 orang nelayan muroami yang sudah berhenti menjadi nelayan muroami akibat peningkatan kesadaran tentang bahaya pekerjaan yang dilakukan, dan 1 orang informan sebagai pemilik kapal atau pengusaha muroami. Triangulasi metode dilakukan dengan mengumpulkan data dengan cara observasi dan wawancara mendalam yang didokumentasikan dengan perekaman percakapan menggunakan video digital, tape recorder, dan kamera digital. Triangulasi data dilihat pada saat melakukan wawancara, informan adalah orangorang yang mempunyai kemampuan berinteraksi dengan orang lain, mereka mempunyai sikap yang supel dan bersahabat. Ketika wawancara, informan tidak merasa canggung memberikan komentar atau jawaban. Selain itu, informan adalah orang yang mempunyai kedudukan atau orang yang menjadi panutan dalam kegiatan penangkapan ikan nelayan muroami. Dengan demikian, diharapkan informasi yang dikumpulkan dapat 
Tabel 1. Alat Penangkapan Ikan Di Pulau Panggang

\begin{tabular}{lll}
\hline Jenis Alat & Jumlah Pemilik & Jumlah Alat \\
\hline Jaring payang & 17 & 220 \\
Jaring dasar & 21 & 21 \\
Jaring gebur & 5 & 75 \\
Bubu besar & 16 & 200 \\
Bubu kecil & 50 & 100 \\
Pancing & 444 & 532 \\
Jaring muroami & 13 & 26 \\
\hline
\end{tabular}

meningkatkan kualitas data.

Sumber data yang digunakan meliputi data primer dan data sekunder. Data primer diperoleh dengan melakukan observasi yang dilakukan dengan mengikuti kegiatan operasi penangkapan ikan muroami dan wawancara langsung dengan nelayan muroami. Data primer yang ingin didapat adalah konstruksi dan cara pengoprasian muroami, tahapan kegiatan penyelaman tradisional, frekuensi pekerjaan, dan sumber-sumber bahaya. Data sekunder adalah data yang didapatkan dari penelusuran pustaka dan dari instansi terkait meliputi profil kabupaten kepulauan seribu, data nelayan muroami yang berprofesi nelayan kompresor dan status kesehatan nelayan yang berhubungan dengan penyelaman. Profil Kabupaten Kepulauan Seribu diperoleh melalui akses internet, data nelayan yang berprofesi sebagai nelayan kompresor didapat melalui Suku Dinas Kelautan dan Perikanan Kepulauan Seribu serta data status kesehatan didapat dari Dinas Kesehatan Kepulauan Seribu.

\section{Hasil}

Kelurahan Pulau Panggang mempunyai luas $\pm 62,10$ Ha dengan kondisi suhu rata-rata berkisara antara $27^{\circ} \mathrm{C}$ $-32^{\circ} \mathrm{C}$. Jumlah nelayan yang berada di Kelurahan Pulau Panggang pada tahun 2009 adalah 1.772 orang yang digolongkan menjadi nelayan tangkap berjumlah 1.536 orang dan nelayan budidaya sebesar 186 orang (Lihat Tabel 1). Satu armada penangkapan ikan muroami biasanya mempunyai sekitar 15 - 18 orang pekerja yang setiap pekerja mempunyai tugas dan tanggung jawab sesuai dengan jabatan dan tugas. Secara garis besar struktur jabatan atau tugas dalam satu unit armada moruami dapat digolongkan menjadi 7 bagian, meliputi pemilik kapal, juragan kapal, kepala kerja, kepala laut, tim pembantu penyelaman, tim darat, dan juru masak.

Operasi penangkapan ikan dengan muroami di Kepulauan Seribu terdiri dari satu unit perahu motor yang terbuat dari kayu berkekuatan mesin 20 - 50 PK berfungsi sebagai pengangkut awak kapal, perbekalan selama melaut, dan 1 unit perahu atau sampan kayu yang tidak menggunakan motor penggerak. Jaring tangsi dalam dan tangsi darat, kerincingan atau penggiring, selang udara, mesin kompresor udara yang diletakkan tepat di depan ruang kemudi sebagai penyuplai udara ketika melakukan penyelaman dan sebagai penampung ikan utama yang dilengkapi dengan palkah yang berada di depan mesin kompresor yang sudah diisi es. Sampan atau perahu yang ditarik oleh kapal motor, dipakai untuk menyimpan jaring kantong, 1 - 2 orang nelayan, dan tempat pengikatan tali kantong pada saat pengoprasian jaring kantong.

Alat penangkap ikan yang dipergunakan oleh nelayan muroami berupa jaring dan kerincingan sebagai penggiring ikan ke dalam jaring kantong. Jaring muroami yang digunakan untuk menangkap ikan terdiri dari jaring tangsi dan jaring kantong. Jaring tangsi atau yang sering disebut dengan jaring pelari berfungsi sebagai pengarah atau penggiring ikan menuju jaring kantong. Jaring tangsi terbuat dari benang plastik atau benang pancing. Saat pengoprasian, jaring tangsi dibagi menjadi dua bagian yaitu jaring tangsi dalam atau tengah yang dipasang di dasar perairan dan jaring tangsi darat yang dipasang di dasar perairan. Jaring kantong berfungsi sebagai jaring penampung ikan setelah ikan yang digiring masuk ke dalam jaring kantong. Jaring kantong terbuat dari bahan bago atau polyethylene yang lebih kuat daripada bahan untuk jaring tangsi.

Kerincingan (lot) merupakan alat penggiring ikan terbuat dari bentangan tali tambang sepanjang 100 meter yang terdapat $7-8$ tali percabangan. Pada setiap percabangan terdapat 1 gelang besi yang diatur jaraknya setiap 7 - 15 meter. Satu gelang besi biasanya digantungi $3-4$ gelang besi. Bentangan tali tambang digantungi rumbai-rumbai atau pita-pita yang terbuat dari plastik berwarna putih. Fungsi dari kerincingan (lot) ini adalah untuk menggiring ikan agar masuk ke dalam perangkap jaring kantong. Tujuan pemasangan kerincing besi tersebut adalah untuk menimbulkan bunyi yang berfungsi untuk menggiring ikan ke arah perangkap, sedangkan fungsi dari rumbai-rumbai adalah untuk menakutnakuti ikan agar ikan tersebut tidak berbalik ke arah penggiring.

Alat bantu penangkapan yang dipakai pada oprasi kegiatan muroami adalah mesin dan penggerak kompresor yang berfungsi menghasilkan udara yang dipergunakan pada proses penyelaman, selang penyalur udara, moutfsih, masker, sepatu karet yang berfungsi melindungi kaki, keranjang plastik untuk membawa hasil tangkapan ke tempat penimbangan, palkah yang dipergunakan sebagai tempat penyimpanan ikan sementara dari hasil tangkapan dan serokan yang berfungsi sebagai alat untuk memindahkan ikan dari palkah ke dalam keranjang. Berdasarkan lama trip melaut nelayan muroami dikelompokkan menjadi dua kelompok meliputi muroami harian yang membutuhkan waktu satu hari mulai 
dari jam 07.00 dan sampai jam 17.30 dan nelayan muroami yang membutuhkan waktu lebih dari satu hari atau yang lebih sering disebut sebagai nelayan muroami "babang".

Tahapan persiapan dilakukan oleh nelayan pada saat menuju lokasi penangkapan (fishing ground) meliputi kegiataan pengecekan bahan bakar, oli mesin kompresor dan tabung kompresor, mengecek alat tangkap dan kerincingan, pengecekan sambungan selang udara dan meluruskan selang yang menggelintir dan pemasangan mouth piece pada selang udara. Apabila lokasi penangkapan sudah dekat, maka juragan laut dan 1 orang anak buah kapal melakukan pengecekan arus dengan cara penyelaman, yang perlu dipersiapkan oleh juragan laut dan anak buah kapal (ABK) adalah memakai baju kerja biasanya baju dan celana panjang, pemakaian teropong semacam penutup kepala dan bagian wajah, peletakan posisi selang penyalur udara, penggunaan pemberat dari timah, sepatu karet dan pemasangan masker pada wajah. Pada saat ini pula mekanik menghidupkan mesin kompresor untuk menyalurkan udara pada selang. Berdasarkan hasil identifikasi bahaya dengan JHA pada aktivitas persiapan, ditemukan bahaya (hazard) ergonomi (strain), kebisingan, terpeleset/tergelincir karena lantai kapal yang licin, mekanik (tertusuk duri ikan, ledakkan tekanan udara yang tinggi pada tabung kompresor, kimia karat, dan tekanan selang api yang korosif dan tekanan udara yang tinggi, kimiawi bahaya oli dan bahan bakar, hantaman (tuas starter yang licin, batu karang serta bahaya yang bersumber dari alam yaitu cuaca ekstrim ombak).

Pengecekan arus dilakukan tampa menggunakan alat khusus berupa GPS (Global Positioning System), tetapi dengan cara merasakan dan memperkirakan berdasarkan insting dan pengalaman kepala kerja dan kepala laut yang melakukan penyelaman dengan menggunakan selang di sambungkan dengan kompresor. Berdasarkan hasil identifikasi bahaya dengan JHA pada aktivitas pengecekan arus, ditemukan bahaya struck againts tergores karang, tekanan ekstrim, temperatur dingin, mekanis gigitan biota laut, kimia berupa sengatan ikan biota laut dan karang beracun, keracunan gas karbonmonoksida (CO), karbondioksida $\left(\mathrm{CO}_{2}\right)$, dan nitrogen, kekurangan pemasukan udara dari kompresor, mechanical failure meliputi selang lapuk atau menekuk, visibility yang jelek, fenomena alam berupa arus kencang, bagian baling-baling yang berputar dan temperatur panas.

Kegiatan yang dilakukan pertama kali pada saat penyetingan alat tangkap adalah pemasangan jaring kantong yang diturunkan dari sampan dipasang di dasar perairan dengan kondisi berlawanan dengan arah arus agar mulut kantong dapat terbuka dengan sempurna. Pemasangan jaring kantong tersebut biasanya dilakukan oleh $3-4$ orang penyelam yang bernafas dengan meng- gunakan selang yang dialiri udara dari mesin kompresor. Kegiatan penyelaman dilakukan beberapa kali yaitu saat mengikat tali ampar pada sebuah batuan karang besar, membawa tali ampar bawah ke sampan untuk di ikat. Setelah pemasangan jaring kantong selesai, tahapan selanjutnya adalah pemasangan jaring tangsi, masingmasing jaring tangsi dipasang oleh 2 tim kerja meliputi 2 orang untuk pemasangan jaring tangsi darat dan 2 orang lagi untuk pemasangan jaring tangsi tengah (dalam). Kedua jaring (kantong dan tangsi) yang sudah terpasang menyerupai bentuk (huruf)" V", biasanya proses setting alat tangkap ini memakan waktu berkisar antara 45 - 60 menit. Setelah proses setting selesai, para penyelam kembali naik ke atas kapal motor untuk bersiap-siap proses penggiringan. Dilihat dari tabel identifikasi bahaya JHA, bahaya yang teridentifikasi pada tahapan ini antara lain: ergonomi (strain), menurunkan jaring, mekanik (tertusuk duri ikan), struck againts (tergores karang), tekanan ekstrim, temperatur dingin, mekanis (gigitan biota laut), kimia (sengatan ikan biota laut dan karang beracun, keracunan gas $\mathrm{CO}, \mathrm{CO}_{2}$ dan nitrogen, kekurangan asupan udara dari kompresor, mechanical failure karena selang lapuk, selang udara menekuk, visibility yang jelek, fenomena alam (arus yang kencang), bagian baling-baling yang berputar dan temperatur panas.

Setelah para penyelam naik ke atas kapal, maka juragan mengemudikan kapal menuju lokasi penggiringan yang berjarak sekitar 200 meter dari lokasi pemasangan alat tangkap. Proses penggiringan dilakukan oleh $7-8$ orang penyelam yang dipimpin oleh seorang kepala laut atau kepala kerja. Penyelam yang bertugas untuk menggiring ikan bersiap-siap kembali dengan perlengkapan selamnya. Sebelum kembali menyelam setiap nelayan akan diberikan tali tambang yang dilengkapi dengan kerincingan, sedangkan untuk nelayan yang tidak menggiring ikan bertugas untuk menjaga selang udara para penyelam agar tidak terjadi penekukan atau terbelit satu sama lain.

Selain menjaga selang kompresor, nelayan darat juga harus memahami kebutuhan para penyelam pada saat berada di dalam laut, kebutuhan para penyelam dapat dirasakan dari isyarat kedutan selang udara, misalnya, apabila penyelam mengedutkan selang 2 kali maka maksudnya adalah bahwa si penyelam tersebut minta agar dia segera ditarik kepermukaan air. Penggiringan dilakukan dengan cara berjalan di atas batuan karang atau pasir dengan posisi tangan menggoncangankan krincingan sekuat mungkin. Proses penggiringan ini dilakukan hingga para penggiring berada pada mulut kantong, dimana proses penggiringan ini biasanya membutuhkan waktu 30 - 45 menit, tergantung dari jarak penggiringan dan kencangnya arus. Jarak antara setiap penggiring adalah sejauh $8-15$ meter, tergantung pada jumlah penggiring. 
Pada kegiatan penggiringan ikan bahaya yang ditemukan berdasarkan hasil JHA hampir sama dengan bahaya yang teridentifikasi pada tahapan pemasangan alat tangkap muroami.

Proses penarikan jaring kantong (hauling) dilakukan oleh $4-7$ orang, tergantung dari hasil tangkapan, semakin banyak hasil tangkapan maka semakin banyak pula tenaga yang dibutuhkan. Proses penarikkan diawali dengan penarikan tali ampar bawah dan tali bulan-bulan untuk menutup mulut kantong, penarikan dilakukan sampai ke bagian poncot yang berisi hasil tangkapan. Setelah hasil tangkapan diangkat ke atas sampan, selanjutnya sampan akan ditarik menuju kapal motor untuk memindahkan hasil tangkapan ke dalam palkah yang sudah di isi dengan es balok. Proses hauling ini terkadang memakan waktu 10 - 20 menit. Potensi bahaya yang ditemukan berdasarkan hasil JHA pada aktivitas pengangkatan hasil tangkap hampir sama dengan bahaya yang teridentifikasi pada tahapan pemasangan alat tangkap muroami dan penggiringan ikan.

Ikan yang dipindahkan ke dalam palkah tidak dilakukan proses penyortiran, terkecuali ditemukan beberapa jenis ikan yang beracun seperti ikan buntal atau ular laut maka ikan tersebut akan segera dibuang kelaut. Penyortiran hasil tangkapan secara keseluruhan baru dilakukan pada saat perjalanan menuju fishing base dengan memisahkan hasil tangkapan berdasarkan nilai ekonomis (jenis), ukuran tubuh dan pemanfaatannya. Terdapat 2 bahaya yang teridentifikasi dengan metode JHA yaitu bahaya ergonomi dan bahaya duri ikan pada aktivitas pengangkatan hasil tangkapan.

\section{Pembahasan}

Pada tahapan ini, terdapat 6 rincian tugas yang masing-masing mempunyai karakteristik yang cukup berbeda, sehingga menghasilkan potensi bahaya yang berbeda pula. Bahaya kebisingan pada aktivitas tahapan persiapan yaitu seluruh aktivitas persiapan seluruhnya dilakukan di depan ruang kemudi. Pengenalan sumber bising ini tidak berdasarkan hasil pengukuran menggunakan sound level meter (SLM) alat pengukur intensitas kebisingan, tetapi hanya berdasarkan penilaian subjektif saja. Sumber bising yang berasal dari mesin kapal bersifat berkesinambungan, karena selama proses bekerja mesin kapal akan selalu hidup, nelayan mulai bekerja dari jam 07.00 pagi hingga jam 17.00 paparan bising selama 10 jam per hari, sedangkan untuk bising yang dihasilkan dari mesin kompresor hanya bersifat sementara.

Pada tahapan persiapan bahaya ergonomi dapat ditemui pada kegiatan pengecekan kondisi selang, mengeluarkan kerincingan dan menghidupkan mesin kompresor. Saat melakukan kegitan pengecekan kondisi selang yang dilakukan selama 20 - 30 menit, kerja otot yang digu- nakan saat berdiri bertumpu pada kedua kaki untuk menahan keseimbangan badan disertai dengan posisi tubuh yang membungkuk. Beban menjadi bertambah ketika kondisi laut sedang berombak besar. Pada pekerjaan mengeluarkan kerincingan dikatakan berpotensi menimbulkan bahaya ergonomi dikarenakan, pada saat melakukan pekerjaan posisi kaki terlalu menekuk, hal ini disebabkan pekerjaan dilakukan sambil jongkok (posisi jongkok). Posisi tersebut dikatakan posisi janggal, karena pada posisi ini banyak terlihat bagian tubuh yang menekuk akan menyebabkan aliran darah terhambat, sehingga apabila itu terjadi akan menyebabkan pekerja mengalami kesemutan dan kelelahan.

Lantai kapal yang licin dapat digolongkan sebagai bahaya karena paparan atau kontak terhadap lantai yang licin ini akan menyebabkan suatu kerugian atau konsekuensi terpeleset. Keadaan seperti itu sudah sering terjadi di kapal nelayan, akan tetapi konsekuensi akibat terpeleset akan semakin parah karena ruang gerak nelayan di atas kapal tergolong sempit yang tidak memungkinkan nelayan bergerak dengan leluasa. Ketiadaan alat bantu berpegangan pada pinggiran kapal, pemakaian alas kaki yang tidak sesuai persyaratan, hingga faktor perilaku (kurang hati-hati) merupakan penyebab lain terpeleset atau tergelincirnya nelayan dari atas kapal. Terluka atau tertusuk duri ikan merupakan konsekuensi yang dapat ditemukan pada tahapan pengecekan kondisi jaring. Pada aktivitas ini nelayan sudah menggunakan sarung tangan, tetapi dari hasil pengamatan terdapat beberapa nelayan yang tidak menggunakan sarung tangan. Selain itu, upaya pengendalian dengan cara pemakaian sarung tangan tidak terlalu efektif untuk mengurangi kosenkuensi akibat tertusuk duri ikan, hal ini karena sarung tangan kain yang dipergunakan tidak efektif untuk menahan atau mencegah tertusuk tangan oleh duri ikan.

Bahaya kebakaran dan ledakan pada aktivitas penangkapan ikan bersumber dari penggunaan mesin bertekanan tinggi dan material atau bahan yang mudah terbakar yang digunakan pada mesin kompresor tersebut. Sumber bahaya kebakaran ini termasuk dalam $h a-$ zard tipe B flammable material. Bahaya kebakaran dan ledakan yang terjadi pada mesin kompresor dapat juga diakibatkan kurang pengontrolan mesin yang tidak dilakukan penggantian oli mesin sesuai dengan jadwalnya. Selain itu, kondisi mesin yang berkarat dapat menyebabkan gram-gram karat masuk kedalam seher mesin, gram-gram karat yang masuk tersebut akan saling bergesekan, apabila dibiarkan semakin lama maka gesekan tersebut dapat menimbulkan panas yang berlebihan sehingga menjadi sumber bahaya kebakaran dan ledakkan.

Bahaya yang ada pada tahapan penangkapan ikan yang dilakukan oleh nelayan muroami, mempunyai efek/konsekuensi yang cukup besar sekali terhadap ke- 
selamatan dan kesehatan nelayan itu sendiri. Pada tahapan ini, ada 4 langkah kerja atau rincian tugas yang harus dilakukan oleh nelayan muroami. Secara umum bahaya yang mungkin timbul berkaitan dengan kegiatan penyelaman adalah bahaya tekanan. Bahaya tekanan ini terjadi karena pada tahapan penangkapan ikan, nelayan muroami harus melakukan penyelaman untuk mendapatkan hasil tangkapan. Potensi bahaya tekanan yang selalu ada pada setiap nelayan muroami melakukan penyelaman, dapat dilihat juga disebabkan oleh faktor perilaku nelayan yang menonjol bekerja tidak memperhatikan aspek keselamatan (safety diving), antara lain motivasi yang kurang, sikap kerja dengan tidak melakukan teknik ekualisasi dan tidak menggunakan alat pelindung diri dan pengetahuan individu nelayan yang tidak mau belajar dari pengalaman serta tidak mendapatkan pelatihan. Penyelaman yang tidak sesuai prosedur ini tentunya sangat membahayakan keselamatan dan kesehatan kerja nelayan muroami.

Temperatur panas ditemukan pada saat aktivitas penurunan jaring kantong dari atas kapal, menuju ke lokasi penggiringan, tim darat yang bertugas menjaga selang udara, dan aktivitas pengangkatan jaring kantong ke atas sampan. Proses perpindahan panas terjadi secara radiasi yang berasal dari energi panas matahari. Upaya pengendalian yang sudah dilakukan berupa penggunaan, teropong semacam kupluk, kaus kaki, sarung tangan, baju kaos lengan panjang dan celana panjang, tetapi perahu tidak dilengkapi dengan atap penghalang panas matahari. Dalam melaksanakan penyelaman, suhu air di sekeliling menentukan kenyamanan dan lama penyelaman. Bahaya temperatur dingin yang memapar nelayan muroami dipengaruhi oleh kedalaman dan waktu penyelaman yang cukup lama. Selain itu, penyelam kompresor hanya mengenakan celana akan berisiko kehilangan panas tubuh yang apabila terjadi secara terus-menerus dan dalam jangka waktu lama dapat berakibat fatal bagi keselamatan dan kesehatan nelayan.

Terdapat beberapa biota laut yang cukup berbahaya, seperti adanya ikan hiu karena ikan ini sangat peka terhadap bau darah, ikan baracuda dapat menyerang bila melihat benda-benda mengkilat seperti benda-benda yang terbuat dari logam, jam tangan. Ikan moray eal dapat menyerang nelayan muroami ketika melewati lubang-lubang karang tempat tinggalnya. Akan tetapi ikan-ikan tersebut tidak menyerang karena kegiatan penyelaman yang dilakukan nelayan muroami membuat ikan-ikan buas tersebut menjadi takut. Dibandingkan dengan serangan biota laut, bahaya biologi berupa sengatan binatang sering dialami oleh nelayan muroami pada saat melakukan penyelaman. Hal ini sangat berbahaya mengingat ketika bekerja penyelam kompresor tidak memakai sarung tangan dan booties sehingga sangat berisiko terkena tumbuhan atau bi- natang lainnya.

Kompresor yang digunakan oleh para nelayan sama persis dengan kompresor pengisi ban kendaraan beroda. Hanya saja, dipakai menyelam karena telah dimodifikasi dengan ditambahkan selang udara panjang digunakan oleh penyelam untuk bernapas melalui mulut. Akan tetapi, tanpa adanya sistem penyaring (filter) dan dekatnya jarak saluran masuk dan knalpot dari kompresor, maka kualitas udara yang dihirup para nelayan menjadi sangat buruk. Berdasarkan hasil proses pembakaran yang terjadi di mesin kompresor akan menimbukan gas $\mathrm{CO}$ dan $\mathrm{CO}_{2}$. Gas $\mathrm{CO}$ sangat berbahaya sekali bila terhirup. $\mathrm{Hal}$ ini disebabkan karena aliran $\mathrm{CO}$ yang terdapat pada darah akan berkombinasi dengan hemoglobin $(\mathrm{Hb})$, sehingga mengurangi kadar oksigen darah dalam tubuh. Gas $\mathrm{CO}_{2}$ terbentuk dari hasil proses pembakaran dalam jumlah tertentu sangat dibutuhkan tubuh untuk mengontrol pernapasan, tetapi dalam jumlah banyak gas ini dapat menyebabkan keracunan.

Pada pelaksanaan keadaan jarak pandang yang terbatas atau visibility yang buruk erat kaitannya dengan kondisi lingkungan (gelombang dan arus air). Jarak pandang yang sangat rendah, sangat berbahaya ketika melakukan aktivitas penyelaman. Pada kondisi ini, penyelam akan kehilangan orientasi dan sulit memprediksi arah arus. Penyelam dapat terbawa arus (terutama arus bawah) dan dapat terbentur benda keras yang ada di sekitarnya. Akibat kehilangan orientasi, penyelam juga berpotensi terbelit peralatan sendiri (selang pernapasan atau tali). Bahaya ergonomi ditemukan pada kegiatan menurunkan jaring kantong dan menarik jaring kantong di atas sampan. Posisi kerja yang dilakukan nelayan tergolong posisi kerja janggal atau posisi kerja yang salah serta beban yang cukup berat dan frekuensi kegiatan penurunan dan pengangkatan jaring yang dilakukan sebanyak 8 kali dengan durasi kurang lebih 10 menit per setting/hauling dapat mempercepat terjadinya kelelahan otot.

Tahapan terakhir ini terdiri dari 2 langkah kerja atau rincin tugas. Terdapat dua bahaya yang teridentifikasi meliputi bahaya ergonomi dan bahaya duri ikan. Tertusuk duri ikan merupakan konsekuensi yang dapat ditemukan pada aktivitas pernyortiran hasil tangkapan. Terdapat tindakan yang tidak aman terhadap proses penyortiran yang dilakuakan secara manual yaitu dengan memisahkan satu per satu hasil tangkapann serta tidak menggunakan sarung tangan (alat pelindung diri). Pada tahapan penanganan hasil tangkapan, pekerjaan ini dilakukan dengan cara posisi jongkok dengan posisi punggung membungkuk, hal ini dikarenakan tidak adanya meja ataupun tempat duduk sehingga apabila hal ini terjadi secara terus menerus dapat menyebabkan nyeri pada area pinggang bawah, akibat dari penekanan sistem saraf di tulang 
belakang. Sering dikenal dengan istilah Low Back pain atau nyeri pinggang bawah.

Penyelaman secara tradisional oleh nelayan muroami tersebut merupakan salah satu pekerjaan di sektor informal yang menurut Bali statement on OHS in the informal sector terdiri dari bisnis skala kecil, bisnis keluarga dan usaha mikro yang lain. Umumnya, bisnis ini merupakan usaha sendiri dan melibatkan anggota keluarga. Keselamatan dan kesehatan kerja di sektor informal dipengaruhi oleh beberapa faktor dalam proses kerja, faktor manusia dan lingkungan kerja meliputi hazard di tempat kerja atau kondisi kerja yang kurang sehat. Faktor penyebab dalam proses kerja adalah material yang ber-hazard, prosedur dan keterampilan kerja, dan perlindungan mesin. Faktor manusianya seperti tingkat pendidikan yang rendah, gizi kurang dan peralatan pelindung diri yang tidak sesuai. Hazard pada lingkungan kerja termasuk aspek fisika, kimia, biologi, ergonomi dan psikososia. ${ }^{6}$ Salah satu kasus kesehatan yang muncul akibat kegiatan penyelamanadalah gangguan pendengaran. ${ }^{7}$

\section{Kesimpulan}

Penelitian ini menghasilkan bahwa proses penangkapan ikan yang dilakukan oleh nelayan muroami dibagi menjadi tiga tahapan utama yaitu tahapan persiapan (pengecekan kondisi selang, pengecekan keadaan dan kondisi jaring, mengeluarkan kerincingan dari palkah, perawatan dan pengecekan mesin kompresor, menghidupkan mesin kompresor dan pemakaian peralatan penyelaman), tahapan penangkapan ikan (pengecekan arus air, pemasangan alat tangkap, penggiringan ikan dan pengangkatan jaring dan kerincingan) serta tahapan penanganan hasil penangkapan (pensortiran ikan, untuk memisahkan ikan berdasarkan jenis dan ukuran dan pemindahan ikan yang telah disortir ke keranjang). Secara umum dari hasil penelitian yang dilakukan, gambaran bahaya yang ditemukan pada aktivitas penangkapan ikan yang dilakukan nelayan muroami dapat digolongkan menjadi dua, yaitu bahaya bagi kesehatan pekerja dan bahaya bagi keselamatan pekerja. Bahaya yang berdampak bagi kesehatan nelayan di antaranya ergonomi, kebisingan, tekanan ekstrim, temperatur dingin dan panas, kimia (sengatan ikatan biota kaut dan karang beracun serta gas $\mathrm{CO}, \mathrm{CO}_{2}$, Nitrogen). Bahaya yang berdampak bagi keselamatan nelayan di antaranya cuaca ekstrim (ombak), terpeleset/tergelincir (lantai kapal yang licin), mekanik (tertusuk duri ikan), struck against (tergores karang), kimiawi (bahaya oli dan bahan bakar), ledakan (tekanan udara yang tinggi pada tabung kompresor), kimia (karat, korosif), tekanan udara tinggi, tuas starter yang licin, batu karang, mekanis (gigitan biota laut), mechanical failure (selang lapuk, menekuk dan bocor), tubuh tersangkut baling-baling kapal, visibility yang bu- ruk dan fenomena alam.

\section{Saran}

Kegiatan penangkapan ikan yang dilakukan oleh nelayan muroami ini sangat berbahaya terhadap keselamatan dan kesehatan pekerjanya, sehingga untuk menghilangkan atau meminimalisasi bahaya tersebut peneliti memberikan beberapa saran yang sekiranya dapat dilakukan bagi elemen-elemen yang terkait. Pemerintah sebaiknya perlu mempunyai tenaga ahli tentang keselamatan dan kesehatan kerja dalam lingkungan pemerintahan setempat. Mengingat pekerjaan ini mempunyai bahaya dan risiko yang besar bagi nelayan muroami, maka sebaiknya perlu dibetuknya pengawas khusus mengenai aktivitas kegiatan penangkapan ikan yang dilakukan oleh nelayan muroami. Perlu digalakkan program-program untuk meningkatkan kesadaran tentang pentingnya keselamatan dan kesehatan kerja. Sebaiknya perlu dibuatnya program pengalihan pekerjaan dari nelayan tangkap menjadi nelayan budidaya yang menjadi prioritas dalam program tersebut adalah nelayan muroami.Untuk para nelayan sebaiknya dilakukan perubahan teknik penggiringan, yang biasanya dilakukan di dalam laut dengan teknik penggiringan ikan yang dilakukan di atas permukaan air. Hal ini bertujuan untuk membatasi waktu terpaparnya atau lamanya melakukan aktivitas menyelam. Mengganti sepatu karet dengan menggunakan fin (kaki katak). Penggantian fin ini bertujuan untuk menambah efisiensi neayan di dalam air serta menambah laju pergerakkan dengan usaha yang seminimal mungkin. Para nelayan sebaiknya melakukan medical chek up secara rutin 3 bulan sekali di Rumah Sakit Mintoharjo serta menggunakan sarung tangan pada setiap melakukan aktivitas kerja untuk memperkecil risiko tertusuk duri ikan, tergores karang, dan terbentur mesin kompresor.

\section{Daftar Pustaka}

1. Salim E. The Environmental impact of the informal sector and the significance of environmental factor to occupational health and safety. In International Conference on Occupational Health and Safety in the Informal Sector. Bali; 1997.

2. COREMAP. Menyelam. 2009 March. Available from: http://www.coremap.or.id/downloads/Menyelam_1151642973.pdf.

3. Divers Alert Network. Report on decompression illness, diving Fatalities and project dive exploration. 2002. Divers Alert Network's Annual Review of Recreational Scuba Diving Injuries and Fatalities Based on 2002 Data. United State America: Divers Alert Network, North Carolina; 2002.

4. Kunaefi TD. Studi population attribute (PAR) pada lingkungan penyelaman tradisional Pulau Barrang Lompo, Makassar. Infomatek. Juni 2003; 5 (2): 100-9.

5. Von BA. Fish catching methods of the world. Fishing News Books Ltd; 1984.

6. World Health Organization. Bali Statement on Occupational Health and 
Kesmas, Jurnal Kesehatan Masyarakat Nasional Vol. 6, No. 4, Februari 2012

Safety in the Informal Sector. International Conference on Occupational Health and Safety in the Informal Sector, Bali 1997. Geneva: World Health Organization; 1995. hal. 15.
7. Thiritz K. Gangguan pendengaran dan keseimbangan pada penyelam tradisional suku Bajo Sulawesi Selatan. Makassar: Bagian THT-KL Fakultas Kedokteran Universitas Hasanuddin; 2005. 